\title{
原子レベル電子顕微鏡と光学的処理 方法を併用した鉱物の構造解析
}

\author{
Application of high resolution electron microscopy and \\ optical diffraction to the structure \\ analysis of minerals
}

\author{
橋本初次郎 (Hatsujiro Hashimoto)* \\ 熊尾 章宏 (Akihiro Kumao)**
}

\begin{abstract}
A model for the $\mathrm{Ca} / \mathrm{Na}$ positions in the superstructure of labradorite feldspar with approximately $50 \mathrm{~mol} \%$ anorthite is proposed on the basis of high resolution electron microscopic structure images and a comparison of the electron diffraction patterns with optical diffraction patterns obtained from masks representing the projected $\mathrm{Ca}$ and $\mathrm{Na}$ atoms. Good agreement in corresponding positions is found between these optical diffraction patterns and the electron diffraction patterns for projections along the four different axes [010], [311], [131] and [5ī1]. The model proposed is the only one which does not contradict the images taken along different crystal directions and the average structure of labradorite (An 55) analyzed by $\mathrm{X}$-ray diffraction.
\end{abstract}

\section{1. はじめに}

鉱物の生成条件や生成機構, 安定関係や物性を知る上で, その微細構造を理解することは 重要であり, その方面の研究が盛んになってきている。その中でも特に斜長石は, その生成 過程の違いによって非常に複雑な微細構造一離溶 (exsolution) あるいは薄層 (lamella) 構 造, 分域 (domain) 構造, 超構造 (superstructure) など一をもって和り, 多くのX線結 晶学者によって構造解析が試みられ, さまざまな構造モデルが提案されてきた。(Megaw (1960), Korekawa and Jagodzinski (1967), Toman and Frueh (1976), Kitamura and Morimoto (1977), Wenk et al. (1980), Horst et al. (1981))。しかしながら, X線によ る構造解析は試料全体の平均構造を与えるのみで, 鉱物生成の歴史あるいは産状によって局 部的に組成が異なったり, 微妙に变化する微細構造が混在する斜長石の構造解析には限界が あるように思える。この限界を越えるため, 電子顕微鏡 (以下電顕), 分析電顕 (Cliff $e t$ al. 1976), 中性子回折 (Tagai et al. 1980) 等が用いられるようになり 新たな情報が提供 され始めたが, 超構造や不完全構造の研究には原子レベル（高分解能）電顕による多波格子 像法が有力である (Hashimoto et al. (1975), Nakajima et al. (1977), Kumao et al.

$*$ 大阪大学工学部

** 京都工芸繊維大学 
原子レベル電子䫓微鏡と光学的処理方法を併用した鉣物の構造解析

(1981))。すなわち，多数の回折波を用いて結像された格子像のコントラストは，撮影条件 をうまく選べば構造の電荷密度分布を二次元的に投影したものに対応するので，電顕像を解 釈することによって原子の種類や位置を推定することがでさ，計算機によるシミュレーショ ンによって構造を確認することができる。

一方, 電子線回折と光回折との類似性を利用して, 二次元的に小孔を配列したマスクによ る光回折像を電子回折像と比較し，銅一金合金における超格子の形成を論じた報告がある。

(Lipson and Michael, 1974)。両者の回折像が一致したからといって，マスクに印された 構造モデルが唯一の正しいモデルの投影とは言えないが，高分解能電顕像やこの像の光回折 像を併用することによって正しいモデルを導き出すことができる。斜長石にみられる反位相 境界を含んだ超構造の像計算は, 単位胞が大きくなり, その中に含まれる原子の数が多すぎ て, 現時点では計算することが困難なので, ここでは, 電顕像, 電子回折像, 小孔による二 次元構造モデルやその光回折像を併用して, ラブラドライト長石の $\mathrm{Ca}$ と $\mathrm{Na}$ の位置を 1 個 1 個区別して決定した方法について述べる。

\section{2. ラブラドライトの構造像における $\mathrm{Ca}$ および $\mathrm{Na}$ 原子のコントラストの差}

斜長石は $\mathrm{Ca}_{x} \mathrm{Na}_{1-x} \mathrm{Al}_{1+x} \mathrm{Si}_{3-x} \mathrm{O}_{8}(0 \leqq x \leqq 1)$ で表すことができる。 $x=1$ のときをア， サイト (An), $x=0$ のときをアルバイト (Ab) と呼び，中間の組成は An100 $x$ で表す。 $\mathrm{Ca}$ と Na が同数含まれていると An50 となる。一般に, An40〜An60 の領域をラブラド ライトと称するが，An25〜An75 の範囲に执いてはX線や電子回折像に特殊な衛星反射を 生じる。この衛星反射は $e$ - 反射と呼ばれ斜長石の超構造に起因しているものである。

薄い結晶に入射した電子波は, 結晶内のポテンシャル場で散乱され結晶の下面に干渉図形 をつくる。軽い原子で構成され, 弱い位相物体とみなされるような非常に薄い結晶に対して は, 干渉図形のコントラストは, 入射電子線方向に投影した結唱のポテンシャル分布に比例 する (Cowley，1959)。結晶下面にできた電子波の強度分布は, 収差のある電子レンズによ って像面に投影されるが，最適な focus 条件 (Scherzer, 1949) に打いては球面収差の影響

\section{$\mathrm{O} \mathrm{Na}$}

- $\mathrm{Al}_{t} \mathrm{Si}$

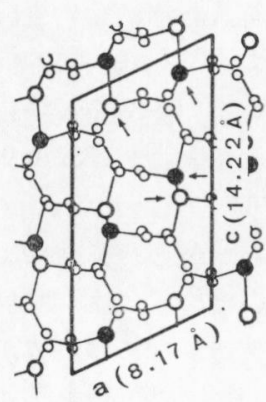

(a)
$C_{s}=0.7 \mathrm{~mm}$

$\Delta f=600 \AA$

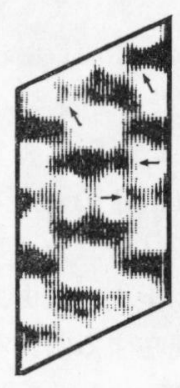

(b)
第1図 (a) アノサイトの構造の中で, $\mathrm{Ca}$ 原子の半数を $\mathrm{Na}$ 原子で置 き換えたモデルを $a c$ 面に投 影したもの。酸素原子は省略 してある。(b)モデルの計算像。
は除かれ，像の強度はポテンシャル分布に比例する ことになる。ある程度の厚さをもった実際の結晶に 対しては, 結晶下面の電子波の強度分布は結晶内の ポテンシャル分布に正確には比例しない。そのズレ の原因は, 多重反射により散乱電子波の位相がずれ るためである。

先に述べたように, 斜長石の構造は複雑でその解 析は今な打続行中のものが多いが, アノサイトの構 造は解析されているので (Wainwright and Starkey, 1971), この構造の中で Ca 原子の半数を $\mathrm{Na}$ 原子で置き換えたモデルを使い, 電子回折の動力学 理論を用いて $\mathrm{Ca}$ と $\mathrm{Na}$ 原子の像コントラストを 計算した結果 (Hashimoto et al., 1975) を第 1 図 に示す。第 1 図(a)は上に述べた構造を $a c$ 面に投影 したもので, (b)は実際のレンズ（球面収差係数 $C_{s}$ $=0.7 \mathrm{~mm}$ ）に対応し，焦点のはずれ量 $\Delta f=600 \AA$, 
結晶の厚さを $60 \AA$ としたときの計算像である。励起波の数は 107, 対物絞りを通って結像 に寄与する波の数を 22 とてある。第 1 図の矢印は $\mathrm{Ca}$ と $\mathrm{Na}$ 原子の位置を示しているが, Ca の位置に叔けるコトラストは Na のそれよりも暗い。したがって, 結晶の厚さが約 $60 \AA$ 程度ならば, ラブラドライトの電顕像に就いて $\mathrm{Ca}$ 原子は $\mathrm{Na}$ 原子より暗いコントラ ストを生じると言ってよい。

\section{3. 薄い結晶の電子回折像と, 構造像あるいは構造を投影した二次元モデルから得られた 光回折像との関係}

結晶の高分解能電䫓写真が最適な focus 条件で撮られたものならば，その写真（元のネガ フィルム) の光回折像は結晶学的な情報を得るのに役立つ (Tanji and Hashimoto, 1978)。 結晶が薄く, 弱い位相物体とみなされるとさ, 位相物体の透過関数 $q(x, y)$ は

$$
q(x, y)=1-i \sigma \varphi(x, y)
$$

で与えられる。 $\sigma$ は interaction constant と呼ばれ, 電圧 $E$ で加速された真空中の電子 波の波長を $\lambda_{0}$ とすると $\sigma=\pi / \lambda_{0} E$ である。 $\varphi(x, y)$ は入射電子線方向に投影された結晶の ポテンシャルを表す。このとき, 電子回折像の振幅分布は (1) 式のフーリエ変換になり, その強度 $E(u, v)$ は振幅の二乗で与えられるので

$$
E(u, v)=\delta(u, v)+\sigma^{2} \Phi^{2}(u, v)
$$

となる。 $\Phi(u, v)$ は $\varphi(x, y)$ のフーリエ変換, $\delta(u, v)$ は二次元の デルタ関数である。 電顕像の振幅分布 $\varphi\left(x_{i}, y_{i}\right)$ は電子回折像の振幅分布をフーリエ変換したものになるが, その二乗が像の強度 $I_{i}\left(x_{i}, y_{i}\right)$ を与兄る。

$$
I_{i}\left(x_{i}, y_{i}\right)=1-2 \sigma \varphi\left(x_{i}, y_{i}\right) * F(\sin \gamma) \text {. }
$$

*はコンボリューションを表し， $\gamma$ は対物レンズの後焦点面に新ける電子波の位相のズレで

$$
\gamma=\frac{\pi}{2 \lambda}\left(C_{\mathrm{s}} \alpha^{4}-2 \Delta f \cdot \alpha^{2}\right)
$$

で与えられる。入は電子波の波長， $\alpha$ は散乱された電子が光軸となす角である。

(3)式で与兄られる強度分布をもつ電顕像から作られた回折像の強度分布 $L(U, V)$ は

$$
L(U, V)=\delta(U, V)+4 \sigma^{2} \Phi^{2}(U, V) \cdot \sin ^{2} \gamma
$$

で与兄れる。(5)式を(2)式と比べると，もし $\sin ^{2} \gamma=1$ ならば $L(U, V)$ は $E(u, v)$ に比例することがわかる。すなわち, $\sin ^{2} \gamma=1$ は「最適な focus 条件」に対応し, 光回折 像は電子回折像と同じになる。しかしながら注意しなければならないのは，この関係は弱い 位相物体近似が適用できるような非常に薄い結晶に対してのみ成り立つといらことである。 厚さ $60 \AA$ 程度のラブラドライトに対しては, 弱い位相物体近似よりも位相物体近似の方が 適当であるかも知れないが，両者の違いは回折斑点の強度に差を生じる程度であろら。

電子回折斑点や光回折斑点の強度は, 散乱機構の違いによっても異なってくる。薄い結晶 中の電子の回折現象は, 三次元的に並んだ原子による電子の散乱であり, 光の回折現象は, 二次元的に配列した小孔による光の散乱である。電子に対する $\mathrm{Ca}$ と $\mathrm{Na}$ の原子散乱振幅 が第 2 図(a)に示されているが, 散乱角の広い範囲にわたって, Ca 原子の散乱振幅は $\mathrm{Na}$ 原 子のほ注 2 倍になっている。一方, 半径 $a$ の円形絞りに光があたったとき, 角度 $\theta$ 方向に 回折された光の振幅は

$$
A(\theta)=C\left(\pi a^{2}\right)\left\{\frac{2 J_{1}[(2 \pi a \sin \theta) / \lambda]}{(2 \pi a \sin \theta) / \lambda}\right\}
$$


原子レベル電子顕微鏡と光学的処理方法を併用した鉱物の構造解析

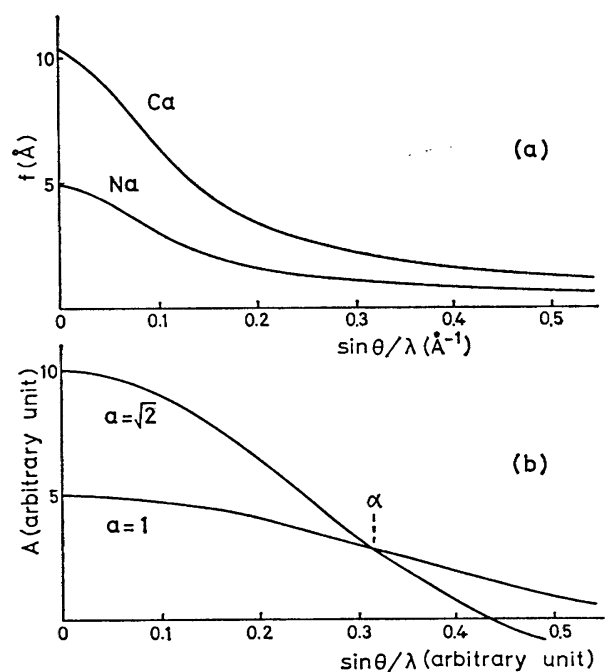

第2図 (a) 電子飞対する $\mathrm{Ca}$ と $\mathrm{Na}$ の原子 散乱振幅。(b) 円形絞りによって散乱 された光の振幅。

となることが良く知られている。入は光の波 長, $J_{1}(x)$ は一次のベッセル関数である。関 数 $J_{1}(x) / x$ は $x=1.220 \pi, 2.233 \pi, 3.234 \pi$, ……，で零になるので，この方们散乱され た光の回折像は消光る。すなわち半径 $a$ の小 孔の場合, 最初に消光る 位置は $(\sin \theta) / \lambda=$ $1.22 /(2 a)$ の方向である。回折斑点を明瞭 に, 例えば間隔 $d$ の格子面による三次の反射 までを明瞭に見るためには $3 / d<1.22 /(2 a)$ ， つまり $a<0.2 d$ を満たさなければならな い。(6)式からわかるように，回折波の振幅 は絞りの面積に比例する。したがって，Ca と $\mathrm{Na}$ の原子散乱振幅の比が $2: 1$ であるこ とに対応して，結晶構造を表す光学モデルに おいては, $\mathrm{Ca}$ と $\mathrm{Na}$ 原子を表す小孔の半径 の比を、 $\sqrt{2}: 1$ にすればよい。このようにし たときの光の散乱振幅が第 2 図(b)に示されて いる。散乱角が小さい時は振幅の比が $2 ： 1$ であるが，岁る角度 $\alpha て ゙ ~ 1 ： 1$ となる。それ 故, 電子回折像と光回折像を比較する場合には, 散乱角 $\alpha$ より内側の範囲が有効となる。

本研究では，入射電子線方向に並んだ原子の列が小孔で表されるが，その直径は各原子の 散乱振幅の平方根に比例して描かれている。Ca と Na が重なる場合は，個々の原子の散乱 振幅をたし合せ，その平均值を使う。このようにして，回折波の位相に寄与する結晶内の原 子位置が，二次元的に配列した小孔の位置で表されることになる。この光学モデルの光回折 像を電子回折像や電顕像の光回折像と比較して, 結晶内の原子位置に関する情報を得ようと するものである。

\section{4. $\mathrm{Ca}$ と $\mathrm{Na}$ の原子位置について}

この実験に用いた試料は組成がAn 54で表されるラブラドライトである(Hashimoto et al. 1976)。現在までに，いろいろな組成の斜長石について構造解析された 結果が報告されてい るが，それらは単に $\mathrm{M}$ 原子（Ca か $\mathrm{Na}$ )， $\mathrm{T}$ 原子（Al か $\mathrm{Si}$ ) 就よ゙酸素原子の位置を定 めた平均構造を示しているにすぎず，また組成が同じであっても解析された結果は少しづつ

第 1 表 $\mathrm{Ca}$ あるいは $\mathrm{Na}$ 原子の座標。左端 の番号は各原子に付けられたもので 文中の説明を通して変ることはない。

\begin{tabular}{cccc}
\hline $\mathrm{Ca} / \mathrm{Na}$ & $x$ & $y$ & $z$ \\
1 & 0.2689 & 0.9767 & 0.0832 \\
$1^{\prime}$ & 0.7689 & 0.4767 & 0.5832 \\
2 & 0.7305 & 0.9729 & 0.4463 \\
$2^{\prime}$ & 0.2305 & 0.4729 & 0.9463 \\
3 & 0.7305 & 0.9729 & 0.9463 \\
$3^{\prime}$ & 0.2305 & 0.4729 & 0.4463 \\
4 & 0.2689 & 0.9767 & 0.5832 \\
$4^{\prime}$ & 0.7689 & 0.4767 & 0.0832 \\
\hline
\end{tabular}

異なっている。本研究の目的は，超構造が $\mathrm{Ca}$ と $\mathrm{Na}$ の配列状態に依存して生ずるもの とし，それらの位置を 1 個 1 個区別して明ら かにすることにある。

光学モデルを作るためには原子の座標が必 要だが，ここでは Toman and Frueh (1973) によって提案された An 55 の平均構造を与 える原子の座標を使う。この構造において彼 らはアルバイトの格子定数 $(c \sim 7 \AA)$ を用い ているが，本研究では超構造をわかりやすく 


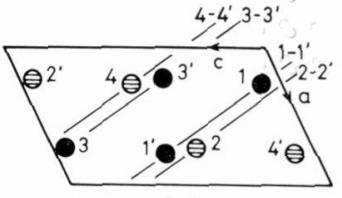

(a)

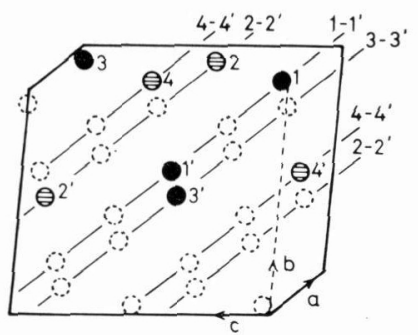

(c)

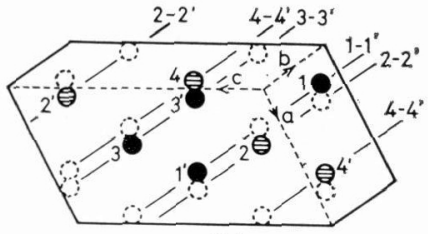

(b)

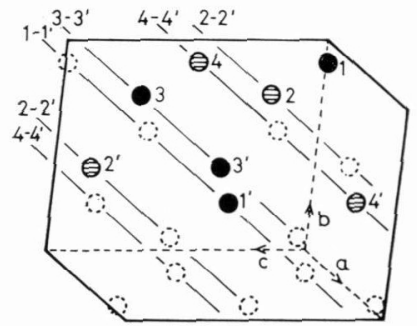

(d)

第3図観察方向に投影された単位胞内の $\mathrm{Ca}$ と $\mathrm{Na}$ の原子位置。 黑丸は $\mathrm{Ca}$ ，斜線をつけた丸は $\mathrm{Na}$ を示す。逆に，黑丸が $\mathrm{Na}$ ，斜線の丸は $\mathrm{Ca}$ としても良い。(a) [010]，(b) [131]， (c) $[511]$, (d) $[311]$.

説明するためアノサイトの格子定数（c〜14 A )を使う。

$$
\begin{array}{lll}
a=8.17, & b=12.86, & c=14.22 \AA \\
\alpha=93.6, & \beta=116.2, & \gamma=89.8 .^{\circ}
\end{array}
$$

Korekawa and Jagodzinski (1967) が導入した座標移行の式 $\mathbf{c} / 2,(\mathbf{a}+\mathbf{b}) / 2,(\mathbf{a}+\mathbf{b}+$ c) $/ 2$ を使うと， 1 個の原子位置から 4 個の位置が導さだされる。こうして求めた $\mathrm{M}$ 原子の 座標が第 1 表に示されている。第 3 図はこの実験で観察された入射電子線の方向 [010], 〔131]，〔511]，〔311〕飞垂直な面に投影された単位胞内の M 原子の位置を示している。黒 丸と斜線をつけた丸は原子の種類の違い（Ca であるか $\mathrm{Na}$ であるか）を表す。この区別は 電顕像から判断するのであるが，こ机については西とで述べる。番号 $1 ， 1^{\prime} ， 2 ， 2^{\prime}$ などは 各原子に付けられたもので, 第 1 表拈よび今後の記述の中で変ることはない。点線の丸は注 目している単位胞以外の M原子の位置である。この図からわかるように，原子 1 と $1^{\prime}$ は投 影面上で 1 つ直線上にのり, 原子 2 と $2^{\prime}$ はこの直線と平行な他の直線上にあることがわ かる。3，3' の原子，4，4' の原子についても同様のことが言えるが，これらの直線上には

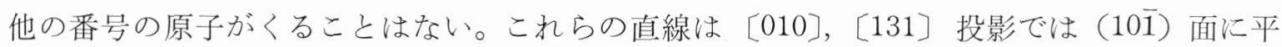

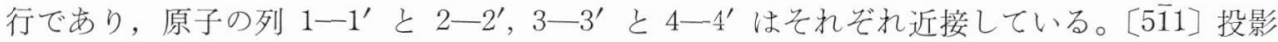
では (011) 面，〔311]投影では $(01 \overline{1})$ 面がそれぞれ直線と平行になるが，いづれも $1-1^{\prime}$ と 3-3'，2-2' と 4-4' が近接していることがわかる。

\section{5. 構造像と回折像}

ラブラドライトをメノウの乳鉢ですりつぶし, これをマイクログリッド上に分散して JEM $100 \mathrm{C}$ 電顕を用いて加速電圧 $100 \mathrm{kV}$ で観察した。厚さ 50 〜 $100 \AA$ の試料に対して，焦点 を変えた一連の電顕写真が撮影された。第 4 図, 5 図, 6 図に電顕像とその光回折像, 電子 
原子レベル電子顕微鏡と光学的処理方法を併用した鉣物の構造解析

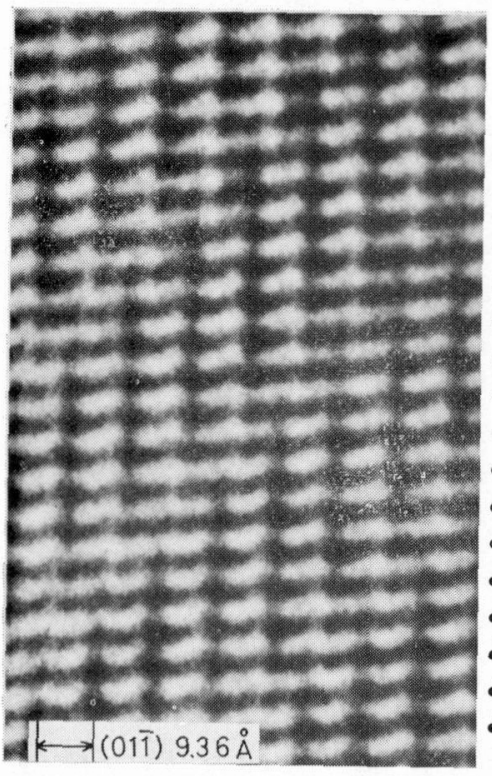

(a)

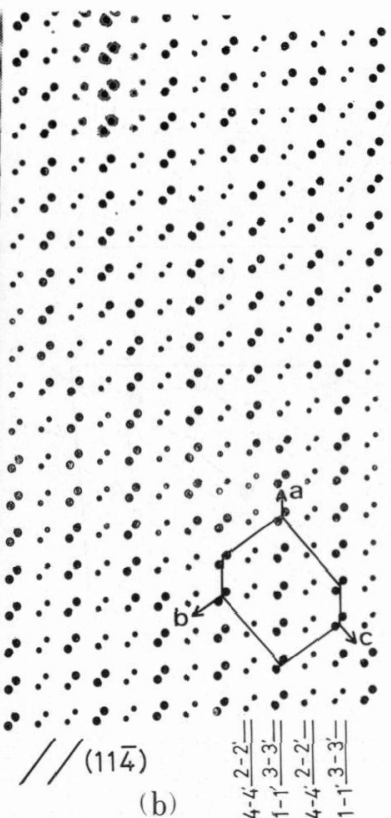

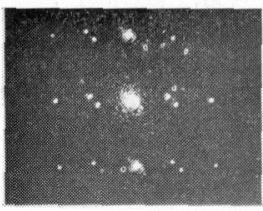

(c)

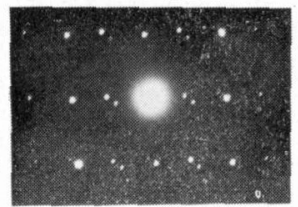

(d)

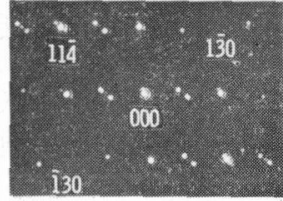

(e)

第 4 図 (a) [311] 万向から撮影された組成 An 54 のラブラドライ トの電顗像。(b) 光回折用モデル。(c) 電顕像の光回折像。

(d) 電子回折像。(e) モデルの光回折像。

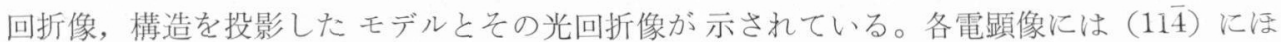
ぼ平行な境界をもった，間隔約 $30 \AA$ の領域がいくつか見党るが，この境界は写真の面に垂

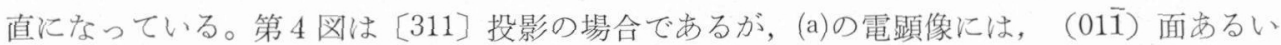
は $a$ 軸に平行に白い点が並んでいるのがわかる。この写真のコントラストと第 3 㘠(d)に示さ れた $\mathrm{M}$ 原子の投影位置とを比較するを，1，1'，3，3'の原子は Ca に対応させ，2，2，4， 4' の原子は $\mathrm{Na}$ に対応させると都合が良いことがわかる。この仮定は, 原子 $1-1^{\prime}$ と $3-3^{\prime}$ は互いに近接し黒いバンドとして現れ，2-2' と 4-4' はも5少し明るいコントラストのバ ンドを形成するといら事実に基づいている。これらのバンドのコントラストは， $a$ 軸に沿っ て9 個の単位胞ごとに, 単位胞内のすべての $\mathrm{Ca}$ 原子が $\mathrm{Na}$ 原子と入れ変り, また逆に, $\mathrm{Na}$ であった場所は $\mathrm{Ca}$ で占有されることを示している。すなわら， $a$ 軸に沿って 9 個の単 位胞ごとに反位相境界が形成されることになる。第 4 図(b)は〔311]方向に投影された Ca と $\mathrm{Na}$ の位置を写真(a) と同じスケールで表した光回折用モデルである。大きな黒丸は 2 個の Ca 原子が重なったものを表し，小さな黑丸は 2 個の $\mathrm{Na}$ 原子の重なりを示す。反位相境界 に所々見られる中間の大きさの黒丸は 1 個の $\mathrm{Ca}$ と 1 個の Na が重なったものである。こ の場合, 大中小の黒丸の直径の比は, $\sqrt{2+2}: \sqrt{2+1}: \sqrt{1+1}=\sqrt{2}: \sqrt{1.5}: 1$ とし てある。各原子列を表す番号を図の右下に表示しておいた。第4 図(a)の電顕像から得られた 


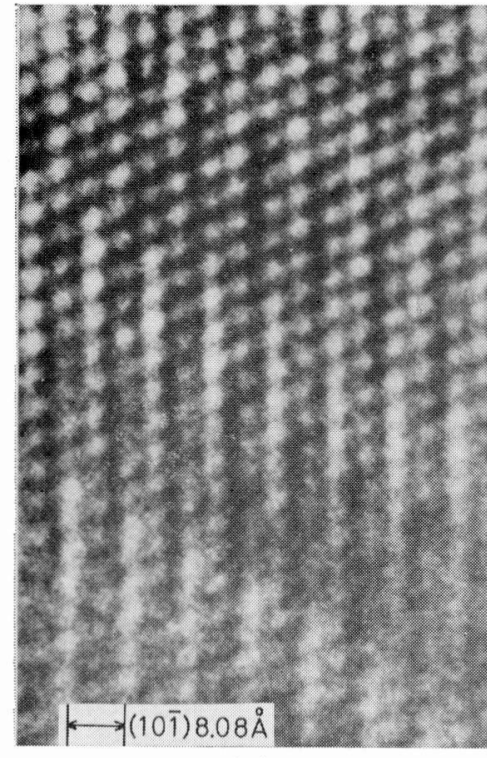

(a)

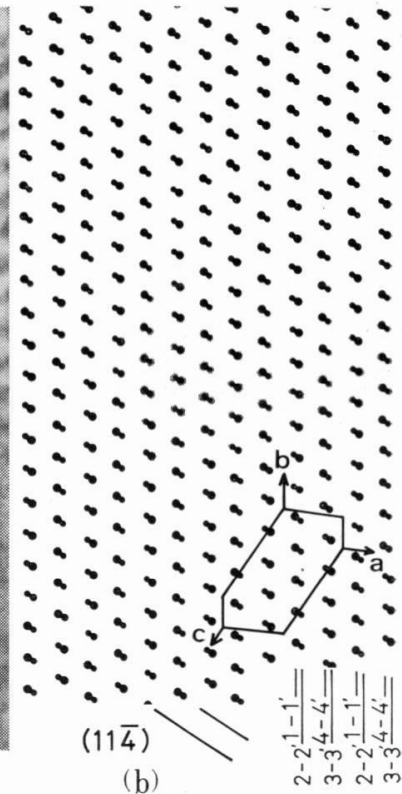

(b)

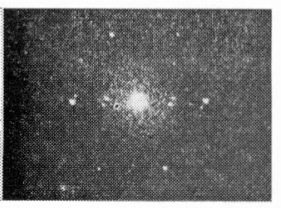

(c)

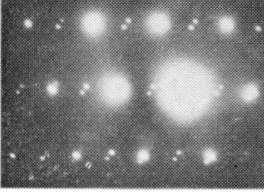

(d)

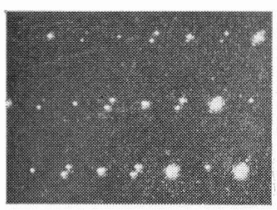

(e)

第 5 図 (a)〔131〕 万向から撮影された電顕像。(b) 光学モデル。 (c) 電顕像の光回折像。(d) 電子回折像。(e) モデルの光回折 像。

光回折像 (c) と電子回折像 (d) は良い対応を示している。このことは, 電顕像が最適な focus 条件で撮影されていることを意味している。モデル(b)の光回折像(e)に和ける 2 つの回折斑点 $1 \overline{3} 0$ と $\overline{1} 30$ が消隇していることを除いて, これら 3 つの回折像は同等の位置に回折斑点を生 じている。回折斑点の消滅は, 光学モデルに使われた一対の孔の距離に依存して現れるので あるが, これについては次節で述べる。回折像に見られる一対の $e-$ 衛星反射の間隔は, 隣 り合ら反位相境界の間隔に対応するものであり, 一対の $e$ - 反射を結ぶ方向はその境界に垂 直な方向である。第 4 図(c)や(d)に見られるこの方向は，(e)のそれと多少異なっている。これ は構造や化学組成が局部的に不均質なため, 境界面にゆらざが生じるためである。ここで特 に強調して扣きたいことは, 第4 図(e) と同様の回折像を与える他の光学モデルもあり得る が, Toman and Frueh (1973) によって提案された平均の結晶構造と電子顕微鏡像両者に 矛盾しないモデルは，第4戝(b)のモデルだけである，といらことである。

第 5 図は〔131]投影の場合であるが，電顕写真 (a) 飞見られる白い点は，紙面に垂直な

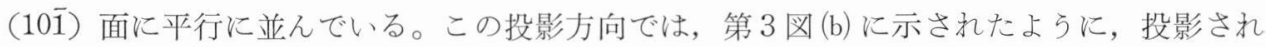
た $\mathrm{Ca}$ と $\mathrm{Na}$ の位置は非常に接近しているのに対して， Ca ぞうしあるいは Na どらしは 離れているので，それらが作るバンド間のコントラストの差は小さい。しかしながら，Ca や $\mathrm{Na}$ の位置を示す第 5 図(b)のモデルと写真のコントラストとの対応は良く, Ca や $\mathrm{Na}$ 
原子レベル電子䫒微鏡と光学的処理方法を併用した鈗物の構造解析

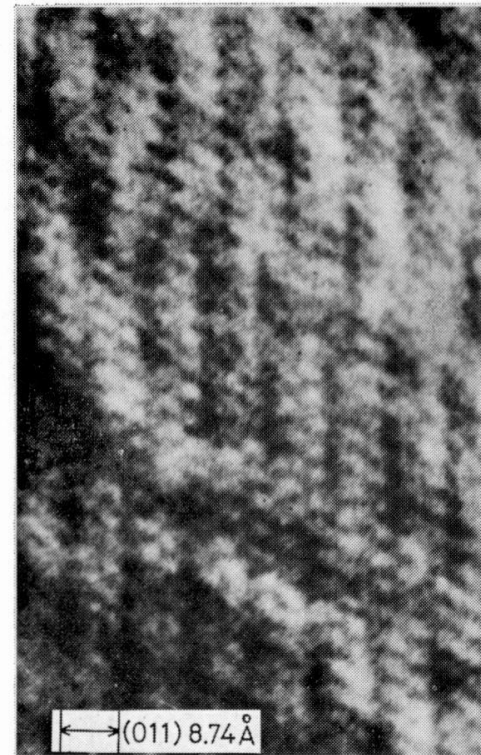

(a)

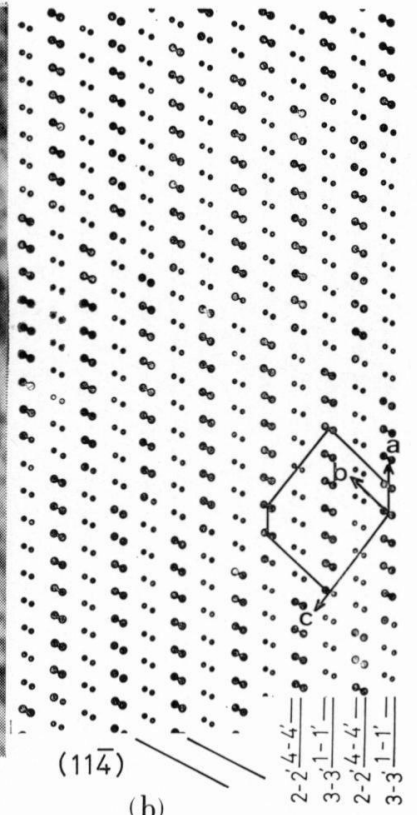

(b)

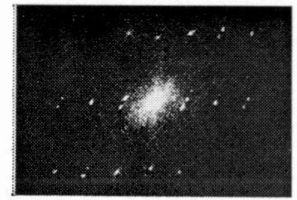

(c)

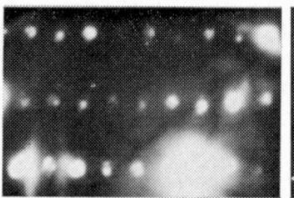

(d)

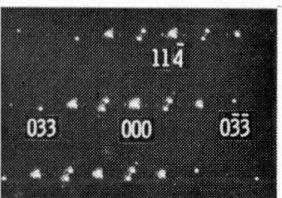

(e)

第 6 図 (a) [511] 方向から撮影された電顕像。(b) 光学モデル。 (c) 電顕像の光回折像。(d) 電子回折像。(e) モデルの光回 折像。

原子の位置は， $b$ 軸に沿って 9 個の単位胞ごとに置換していることがわかる。第 5 図(c)は電 顕像の光回折像, (d)は電子回折像, (e)はモデルの光回折像であるが, 回折斑点の位置関係は 良い対応を示している。

第6 図は〔511]投影の場合で, 写真とモデルがそれぞれ (a)と(b) に示されている。写真の 黒いコントラストのバンドは $\mathrm{Ca}$ 原子の投影位置に対応して拈り, (011) 面あるいは $a$ 軸に 平行に並んでいることがわかる。〔311〕投影の場合と違って, 反位相境界が明瞭でないが, これは電子線に対して試料が部分的に傾いてブラッグ条件からはずれているためである。第 6 図(c)は電顕像から得られた光回折像, (d)は電子回折像である。この回折像からわかること は，試料がやや厚く，明るい像を得るためビームを絞り，そのためビームの開き角が大き くなって回折斑点がぼけてしまったことである。また, 試料全体も電子線に対して正確に [511]方向にないこともあって, $e-$ 反射が明確に 分離されていない。電子回折像を第 6 図 (c)扣よびモデルの光回折像(e)と比較する時は, 上記の事柄を考虑しなければならない。

\section{6. ラブラドライトの超構造モデルの組立て}

$\mathrm{Ca}$ や $\mathrm{Na}$ の投影位置について述べてきたが，厚さ方向の重なり具合はどうなっているの だろうか。[010]投影では言うまでもなく, ある単位胞内の番号 1 や 2 の原子の上下には, 


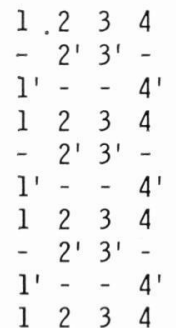

(a)

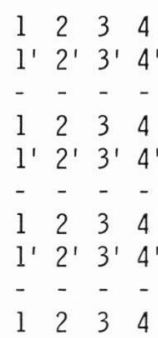

(b)

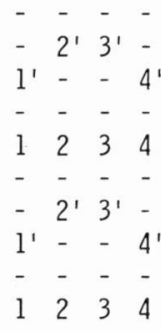

(c)

第 7 図 (a) [311]，(b) [131]，(c) [5111] 万向の Ca あるいは $\mathrm{Na}$ 原子の積又重なり方を 示す。番号以第 1 表や第 3 図に示された 原子に対応している。

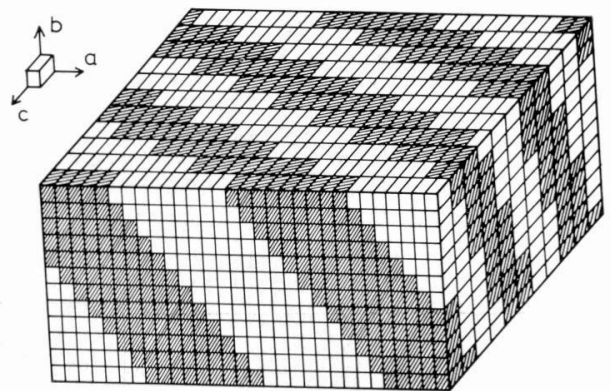

第 8 図組成 An 50 の超構造モデル。白い部分 と斜線部分では, Ca と $\mathrm{Na}$ の位置が反 位相の関係になっている。

同じ番号の原子がある。〔311]，〔131]，〔5111〕方向の投影に対するM原子の重なり方は，㶢 れぞれ第 7 図(a)，(b)，(c)に示されている。この図からわかることは，〔311】，〔131〕投影で は 3 層ごとに同じ番号の原子が繰り返し積み重なり，〔511〕投影では 5 層ごとに同じ原子が 繰り返し現れることである。先に，水平方向で 1 - $1^{\prime}$ や 2 - $2^{\prime}$ の原子による列がでさること を述べたが，垂直方向でも $1-1^{\prime} や 2-2^{\prime}$ の原子によるグルーブができることがわかる。し たがって，試料が厚くなっても $1-1^{\prime} ， 2-2^{\prime} ， 3-3^{\prime}, 4-4^{\prime}$ の各グループの原子数の割合は 汪とんぞ変らず，それらのグループによる投影方向のポテンシャルの比は一定とみなすこと ができる。第 4 図, 5 図，6図の光回折モデルは，繰り返しの単位（ 3 層あるいは 5 層）を 用いて描いてある。

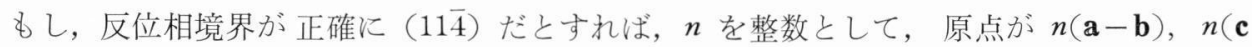
$+4 \mathbf{a}), n(\mathbf{c}+4 \mathbf{b})$ にある単位胞内の原子は，原点にある単位胞内の原子と全く同じ配置を とらねばならない。なぜならば，それらの単位胞の原点は（114）飞平行な同一の面内にあ り, 電顕像や光学モデルから解るように，2つの境界にはさまれた領域では単位胞内の原子 の配列状態は同じになる必要があるからである。ここに述べた規則性と，前節で述べた $a$ 軸 㧈よび $b$ 軸に沿って 9 個の単位胞ごとに $\mathrm{Ca}$ と $\mathrm{Na}$ が置換する規則を考えると，第 8 図の ような超構造モデルができる。白い領域では，原子 $1 ， 1^{\prime} ， 3 ， 3^{\prime}$ は Ca であり，2，2，4， 4' は $\mathrm{Na}$ である。斜線部分では逆で，原子 1，1'，3，3’ は $\mathrm{Na} ， 2 ， 2^{\prime} ， 4 ， 4^{\prime}$ は Ca で ある。すなわち，両者は反位相の関係になっている。

このモデルを用いて， $b$ 軸方向の 1 層に含まれる $\mathrm{Ca}$ と $\mathrm{Na}$ 原子を $a c$ 面に投影した光学 モデルが第 9 図(a)である。大さい黒丸は $\mathrm{Ca}$ ，小さいものは Na である。また，第 8 図に対 応して反位相境界が点線で示してある。このモデルの光回折像が第 9 図(d)であるが，(c)の電 子回折像と比べて, 余分な位置に衛星反射が生じている。これは, 〔010]投影の場合には, 反位相境界 (11 $\overline{4})$ が $b$ 軸に対して傾いているため，境界付近の原子配列の乱れが 回折像に 影響を及ぼすからである。第 9 図(a)に示された点線付近の $\mathrm{Ca}$ と $\mathrm{Na}$ の配置を改善したモ デルが(b)であり，その光回折像が(e)であるが，回折斑点の位置は電子回折像と良い一致を示 している。第10図は第 9 図(a)と(b)の光学モデルの違いを簡単に表したものである。第 9 図(a)

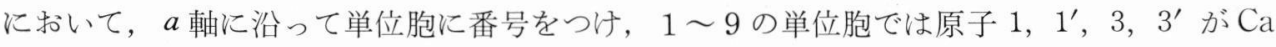
(黒丸)，原子 $2 ， 2^{\prime} ， 4 ， 4^{\prime}$ は $\mathrm{Na}$ (白丸）とする。10１8の単位胞では全く逆の配置状態 である。第 9 図(b) の改良されたモデルでは, 番号 1 と 2 の単位胞で $2^{\prime}$ の $\mathrm{Na}$ 原子と 3 の 


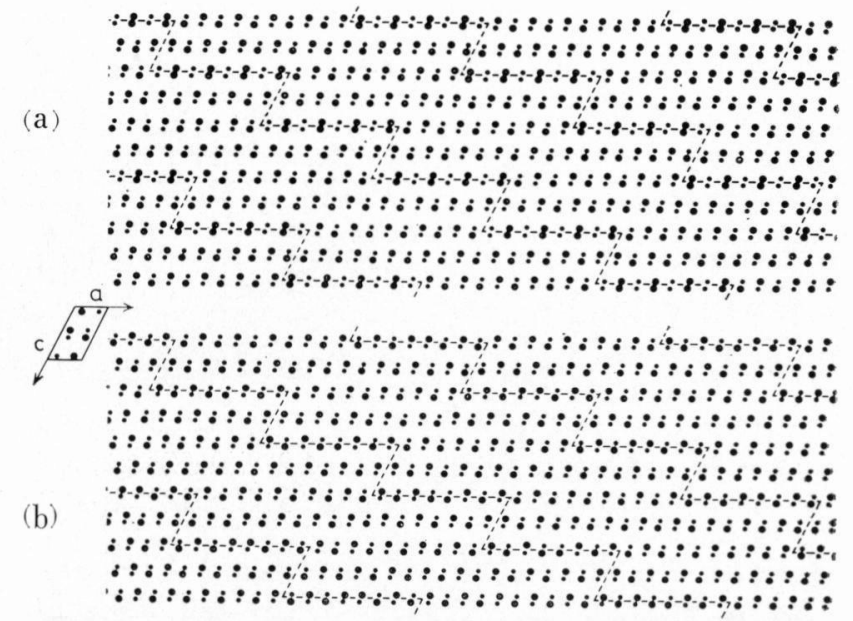

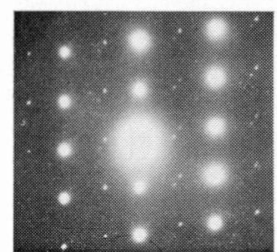

(c)

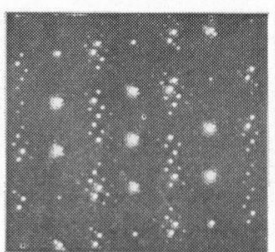

(d)

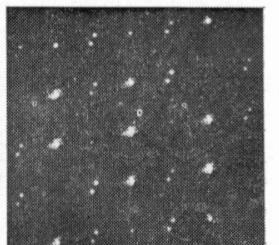

(e)

第9図 $b$ 軸方向の 1 層に含まれる $\mathrm{Ca}$ と $\mathrm{Na}$ を $a c$ 面に投影 した光学モデル。反位相境界 (点線) に新ける Ca と $\mathrm{Na}$ の配置の乱れを考虑しないモデル (a) と考慮したモ デル(b). 兩者の違いは第10図に示されている。(c)電子回 折像。(d)モデル(a)の光回折像。(e)モデル(b)の光回折像。

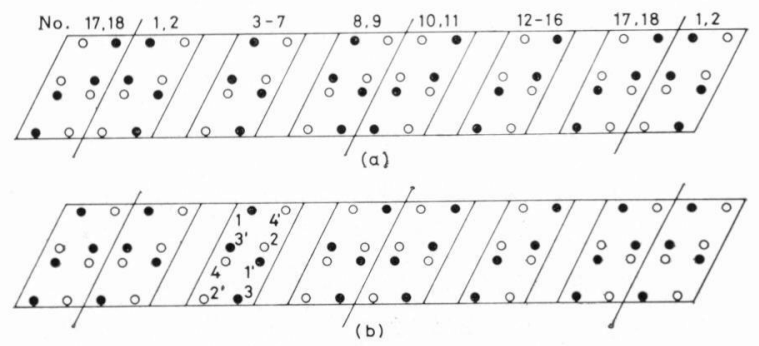

第10図 境界付近での $\mathrm{Ca}$ と $\mathrm{Na}$ の配置状態の違いを示す [010] 投影の略図。黒丸は $\mathrm{Ca}$, 白丸は $\mathrm{Na}$ 。(a) 第 9

図(a)のモデル。(b) 第 9 図(b)の改良されたモデル。

$\mathrm{Ca}$ 原子をそれぞれ $\mathrm{Ca}$ と $\mathrm{Na}$ に置き換える。また 8 と 9 の単位胞では原子 1 を $\mathrm{Na}$ に, 4'を $\mathrm{Ca}$ に置き換える。同様にして, 番号 10 と 11 の単位胞では原子 $2^{\prime}$ と 3 を, 17 と 18 単 位胞では 1 と' の原子をそれぞれ置き換えることによって正しいモデルを得ることができ る。

この改良されたモデルを用いて， $b$ 軸方向に 9 層重ねた場合の光回折用モデルが第11図(a). に示されている。この投影方向では，反位相境界が斜めになっているため，Ca と Na の重 なり方が場所によって異なってくる。一番大きな黒丸は 9 個の $\mathrm{Ca} の$ 重なりを表し, 一番小 


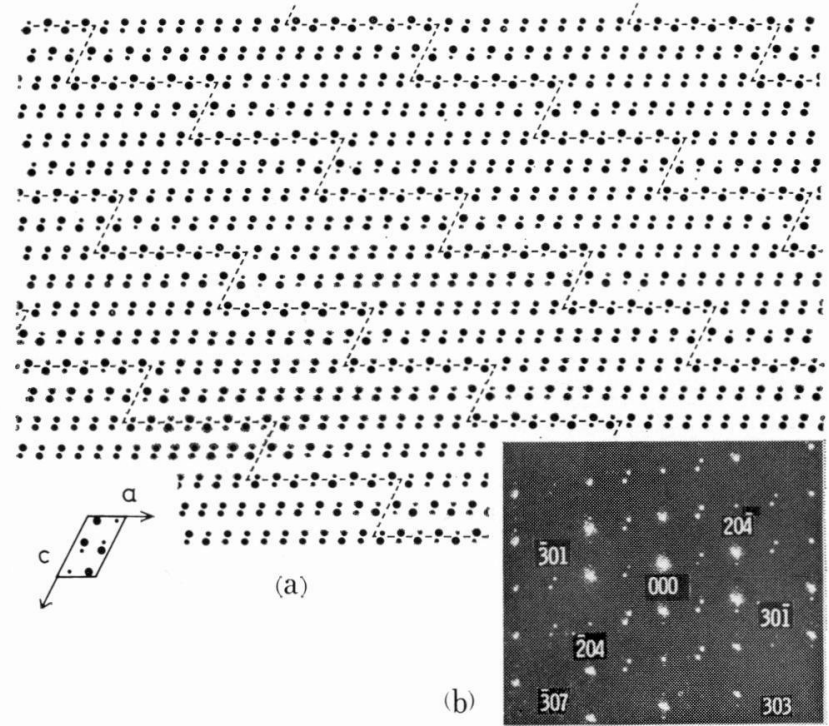

第11図 (a) $b$ 軸方向の 9 層に含まれる $\mathrm{Ca}$ 之 $\mathrm{Na}$ の重なり具 合を示す光学モデル。(b) このモデルの光回折像。

さな黒丸は 9 個の $\mathrm{Na}$ が重なったものである。点線で表した反位相境界に挾まれた中央部分 は， Ca と Na が注济同数重なるので黒丸の大きさも核济同じになっている。これらの黒丸 の直径は, $\mathrm{Ca}$ と $\mathrm{Na}$ の重なり具合を考慮して, それらの原子散乱振幅の平均值の平方根に 比例して描かれている。第11図(b)はモデル(a)の光回折像であるが， 1 層だけのモデルの光回 折像，第 9 図(e)と比べて注とんど同じである。

ところで，モデルの光回折像には回折斑点が消滅していたり，強度が非常に弱かったりす ることがある。例えば第11図(b)で，303 や 307 の衛星反射が消光ているが，これは 3 節で 述べたように，小孔による光の回折現象に依存するものである。一方，204 や 204 は他の $a$ - 反射（分離していない反射）に比べて非常に弱いし，301 や $\overline{3} 01$ の衛星反射は消隇して いる。これらの現象は一対の孔による回折効果によって説明することができる。いま, 間隔 $d$ だけ離れた一対の小孔が，これらを結ぶ方向に $D(D>d)$ の間隔で沢山並んでいる場合 を考劣てみる。これによる光の回折像は, 孔の列に垂直で, 間隔 $1 / D$ で並んだ直線として 現れるのであるが， $1 / 2 d, 3 / 2 d, 5 / 2 d, \cdots \cdots$ の位置では回折強度は零になる。第 6 図 (e) は

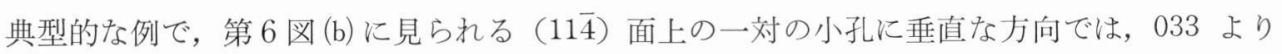
大きな指数の回折斑点が消えている。この効果による回折斑点の消隇や弱まりは他の光回折 像に拄いても見ることができる。

\section{Al あるいは $\mathrm{Si}$ 原子の回折像に及ぼす役割}

ラブラドライトの超構造を解明するにあたり, Al や $\mathrm{Si}, \mathrm{O}$ 原子の存在を考慮しなかった が, ここでは, $\mathrm{Al}$ あるいは $\mathrm{Si}$ 原子を光回折モデルに付け加えてみる。 X 線解析で $\mathrm{Ca}$ と $\mathrm{Na}$ の位置を区別できなかったのと同じく, $\mathrm{Al}$ と $\mathrm{Si}$ も区別されていないので, 平均構造 から求められたT原子 ( $\mathrm{Al}$ か $\mathrm{Si}$ ) の座標を使う。また， $\mathrm{Al}$ と $\mathrm{Si}$ の原子散乱振幅は同じ とみなして差支えないので，モデルの黒丸の大きさはA1 の原子散乱振幅の平方根に比例す 


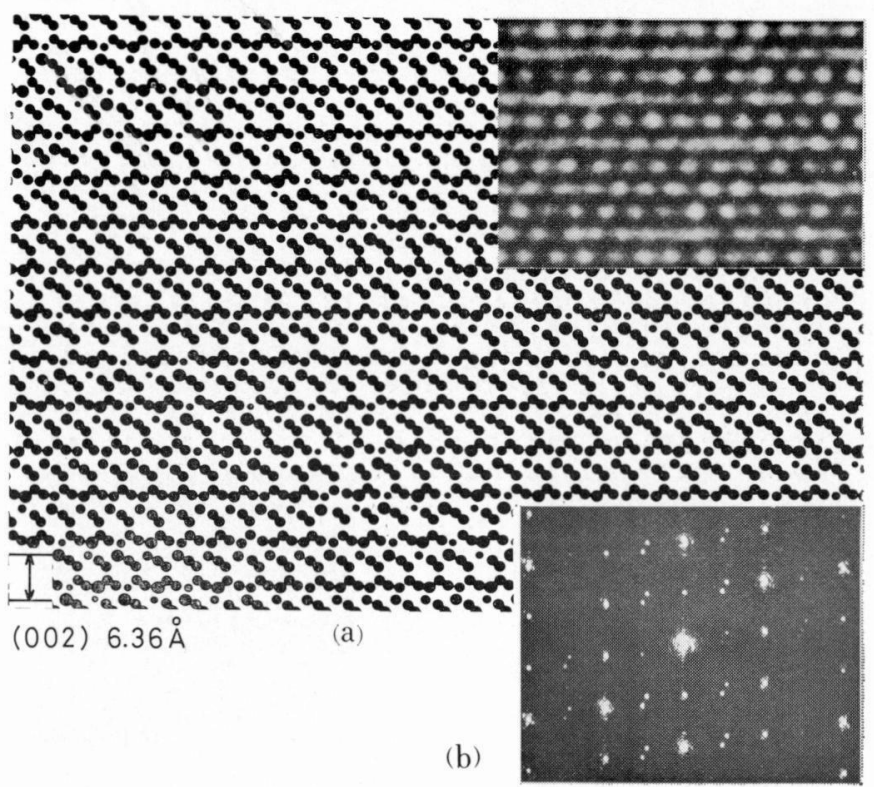

第12図 (a) 図11(a)に Al 原子を加えた光学モデル。電顕像が同 じスケールで挿入されている。(b) モデルの光回折像。

るように決めた。第12図 (a) は，〔010〕方向に単位胞を 9 個積み重ねた場合の， Ca， Na， Al を含んだ光回折モデルである。つまり，第11図(a)に Al が付け加わったものである。モデル と同じスケールで電顕写真が插入されているが，反位相境界が紙面に垂直でないため，それ によるコントラストの差は小さく観察されない。モデルの光回折像が第12図(b)であるが，第

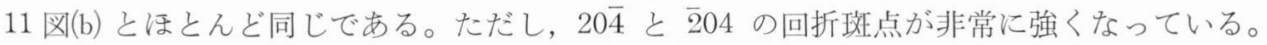
これは $\mathrm{A} 1$ が付加されたために，もはや，前節で述べたような一対の黒丸が形成されなくな り，回折効果の影響が除かれ本来の強度が現れたものである。このように，Al を回折モデ ルに入れても回折斑点の位置は変らす゚, 超構造に依存する $e$ - 反射に何ら影響を及ぽさない ことがわかる。実際には，Al と Si の間にわずかながら散乱振幅の差があるが，回折強度 に及ぼすその差の影響は，Ca と Na の場合に比べて非常に小さく無視してよいであろう。 また, 酸素は原子散乱振幅が $\mathrm{Al}$ や $\mathrm{Si}$ の $1 / 3$ であり, 反位相境界で特にその位置を変光 ることもないので, 酸素原子を付加しても光回折強度が多少変る程度で, 超構造モデルを考 える際には酸素の存在を考慮しなくても良いと思われる。

\section{8. おわりに}

斜長石に複雑な構造があることが Chao and Taylor (1940) によって発見されて以来, X線解析に基づいたラブラドライトのさまざまな構造モデルが多くの研究者によって提案さ れてきたが, 超構造の解析に関しては相入れない部分が多い。本稿では, 高分解能電顕写真 之電子回折像特よび光回折法を利用して, 組成が An 50 のラブラドライトの構造, 特に Ca と Na の位置を 1 個 1 個区別した方法について述べてきた。この方法は An 67 の斜長石に も応用され構造が解析されている (Kumao et al. 1982)。

現時点では, 超構造を含导電顕像の計算をすることは困難なので, 電子回折の多波動力学 


\section{橋本初次郎, 熊尾 章宏}

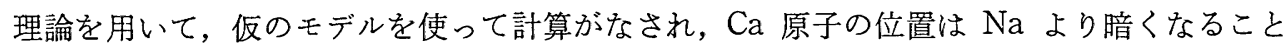
が示された。この結果から, 第 4 図, 5 図, 6 図の電顕写真に見られる明暗の縞模様は, $\mathrm{Ca}$ と $\mathrm{Na}$ の配列状態に依存して生じるものであることが結論づけられた。

一方, 結晶構造の投影に対応して二次元的に小孔を配列したモデルによる光回折像は，特 に反位相境界が入射ビームと平行でない場合，境界に括ける $\mathrm{Ca}$ と $\mathrm{Na}$ の位置を改善する のに有効であった。第 4 図，5図，6図に示された光回折モデルは，この改良されたモデル を用いて作られたものであったが，これらの図に拈ける投影方向 [311]，〔131]，[5

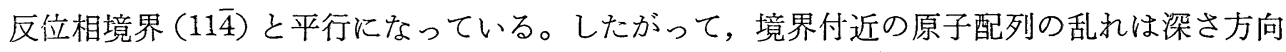
の配列に影響を及ぼすのみで，モデルの光回折像には乱れの影響はほとんど現れない。

本研究に用いた試料は組成が An 54 であり，Ca と Na の原子位置を決めるためには An 55 の平均構造を示す座標が使われ，をた，超構造モデルは An 50 を仮定するといらよ らに組成は不統一であるが，現時点ではこれらを問題にする必要はない。困に示された電顕 写真には，不規則に分布した点状のコントラストの乱れが観察される。この異常なコントラ ストは， Na であるべき所に $\mathrm{Ca}$ が入っているといった組成上の乱れによって生ずるもので ある。一般に，これらの乱れは電顕像には現れても，電子回折像で検出することは困難であ る。したがって，不規則に分布する点欠陥が試料の組成に応じて存在するならば，An 50 と An 54 に护ける $\mathrm{Ca}$ と $\mathrm{Na}$ の位置の違いを識別することはできないであろう。本稿は光回 折法に限界があることを認めながらも，超構造を含む複雑な結晶構造を解析する手段とし て, 高分解能電顕像と電子回折像, 扣よび光回折法の併用が有効であることを指摘するもの である。

\section{文献}

Chao, S. H. and Taylor, W. H. (1940): Isomorphous replacement and superlattice structures in the plagioclase feldspars. Proc. Roy. Soc. London, 176 A, 76-87.

Cliff, G., Champness, P. E., Nissen, H.-U. and Lorimer, G. W. (1976) : Analytical electron microscopy of exsolution lamellae in plagioclase fedspars, in Electron Microscopy in Mineralogy, (Ed) H.-R, Wenk et al., Springer-Verlag, Berlin, pp. 258-265.

Cowley, J. M. (1959): The electron-optical imaging of crystal lattices. Acta Cryst., 12, 367375.

Hashimoto, H., Kumao, A., Endoh, H., Nissen, H.-U., Ono, A. and Watanabe, E. (1975): Lattice image contrast in many-beam dynamical theory and structure determination of labradorite feldspar, in Developments in Electron Microscopy and Analysis, (Ed) J. A. Venables, Academic Press, London, pp. 245-250.

Hashimoto, H., Nissen, H.-U., Ono, A., Kumao, A., Endoh, H. and Woensdregt, C. F. (1976): High-resolution electron microscopy of labradorite feldspar, in Electron Microscopy in Mineralogy, (Ed) H.-R. Wenk et al., Springer-Verlag, Berlin, pp. 332-344.

Horst, W., Tagai, T., Korekawa, M. and Jagodzinski, H. (1981): Modulated structure of a plagioclase An 52, Theory and structure determination. Z. Krist., 157, 233-250.

Kitamura, M. and Morimoto, N. (1977): The superstructure of plagioclase feldspars. Phys. Chem. Minerals, 1, 199-212.

Korekawa, M. and Jagodzinski, H. (1967): Die Satellitenreflexe des Labradorits. Schweiz. Min. Petr. Mitt., 47, 269-278.

Kumao, A., Hashimoto, H., Nissen, H.-U. and Endoh, H. (1981) : Ca and Na positions in 
原子レベル電子顕微鏡と光学的処理方法を併用した鉱物の構造解析

labradorite feldspar as derived from high-resolution electron microscopy and optical diffraction. Acta Cryst., A 37, 229-238.

Kumao, A., Nissen, H.-U. Wessicken, R. and Naiki, T. (1982) : Superstructure of calcic plagioclase studied by HREM and optical diffraction. Proc. 10 th Int. Congr. Electron Microscopy, Hamburg, vol 2, 23-24.

Lipson, H. and Michael, W. S. (1974) : Optical-diffraction methods of studying the electrondiffraction patterns of thin films of copper-gold alloys. J. Appl. Cryst., 7, 577-585.

Megaw, H. D. (1960): Order and disorder, II. Theory of diffraction effects in the intermediate plagioclase feldspars. III. The structure of the intermediate plagioclase feldspars. Proc. Roy. Soc. London, 259 A, 159-183, 184-202.

Nakajima, Y., Morimoto, N. and Kitamura, M. (1977): The superstructure of plagioclase feldspars. Phys. Chem. Minerals, 1, 213-225.

Scherzer, O. (1949): The theoretical resolution limit of the electron microscope. J. Appl. Phys., 20, 20-29.

Tagai, T., Joswig, W., Korekawa, M. and Wenk, H.-R. (1980) : Die Bestimmung der Al/SiVerteilung mittels Neutronenbeugung in einem Plagioklas An 66. Z. Krist., 151, 77-89.

Tanji, T. and Hashimoto, H. (1978): Optical selected-area diffraction patterns of highresolution electron-microscope images for crystal analysis. Acta Cryst., A 34, 453-459.

Toman, K. and Frueh, A. J. (1976): Madulated structure of an intermediate plagioclase. I. Model and computation. II. Numerical results and discussion. Acta Cryst., B 32, 521$525,526-538$.

Toman, K. and Frueh, A. J. (1973): On the centrosymmetry of intermediate plagioclases. Z. Krist., 138, 337-342.

Wainwright, J. E. and Starkey, J. (1971): A refinement of the structure of anorthite. $Z$. Krist., 133, 75-84.

Wenk, H.-R., Joswig, W., Tagai, T., Korekawa, M. and Smith, B. K. (1980) : The average structure of An 62-66 labradorite. Am. Mineral., 65, 81-95.

（昭和57年12月15日 受理） 